\title{
Levels of some plasma fibrotic factors and hepatic nitric oxide synthase in experimentally induced cirrhotic rats
}

\author{
Eman M Fawzy ${ }^{1}$, Mohammed $S$ Gad $^{2}$ \\ and Ehsan M H Abd Al-Rahman ${ }^{3}$. \\ Departments of Phyiology ${ }^{1}$, Internal Medicine ${ }^{2}$ and Medical \\ Biochemistry ${ }^{3}$ Faculty of Medicine, Alexandria University
}

\begin{abstract}
Hepatic fibrogenesis is a consequence of hepatic stellate cells that become activated and transdifferentiated into a myofibroblastic phenotype with the ability to proliferate and synthesize large quantities of extracellular matrix components. Aim: The aim of the present study was to investigate plasma levels of tumor necrosis factor alpha (TNF- $\alpha$ ) and interleukin-6 (IL-6) as proinflammatory and profibrogenic cytokines in cirrhotic rats and relate them with the level of plasminogen activator inhibitor-1(PAI1) as a marker of fibrinolytic activity. In addition, these cytokines were correlated with hepatic nitric oxide synthase activity (NOS). Subjects and methods: The study included 31 cirrhotic rats and 10 healthy controls. Induction of cirrhosis; Hepatic injury and fibrosis were done in rats by intraperitoneal injection (IP) of dimethylnitrosamine.(DMN). That were divided into 5 groups. Group I: as a control, group II were 8 cirrhotic rats, while group III were 7 cirrhotic ones with ascites. Group $I V$ and $V(n=8$ rats) were cirrhotic rats injected with $N g$ nitro L-arginine methylester (L-NAME). Group $V$ were ascitic in addition. Plasma TNF- $\alpha, I L-6$ and PAI-1 and nitric oxide (NO) metabolites were measured. Hepatic nitrite level and NOS activity were also estimated. Results: Plasma TNF- $\alpha$ was significantly increased in all studied groups compared to control group. Plasma IL-6 was significantly higher in cirrhotic group with ascites and L-NAME administered groups compared to control one. Levels of plasma IL-6 were increased progressively with evolution of the disease. There was no statistically significant difference in plasma levels of PAI-1 between cirrhotic rats and control group, whereas, it was significantly increased in cirrhotic group with ascites upon L-NAME administration compared to control group. NOS activity is positively correlated with hepatic nitrite level. A positive significant correlation, also, existed between plasma TNF- $\alpha, I L-6$ and NOS activity and hepatic nitrite in cirrhotic rats. Conclusion: The present study revealed that in cirrhotic rats; plasma levels of TNF- $\alpha$ and IL- 6 were significantly elevated, and the elevation was more with progression of fibrosis. Plasma PAI-1 was increased in severe fibrotic liver with other injury. It could be suggested that the profibrogenic cytokines TNF- $\alpha$ and IL- 6 are implicated in fibrogenesis in cirrhotic rats and are correlated with NOS activity which functions as an adaptive mechanism. They could be used clinically as indicators for occurrence and progression of fibrosis.

Key Words: Hepatic fibrosis, cirrhosis, tumor necrosis factor- $\alpha$, interleukin- 6 , plasminogen activator inhibitor-1, nitric oxide, nitric oxide synthase.

Abbreviations: TNF- $\alpha$ : Tumor necrosis factor- $\alpha$, IL-6: Interleukin-6, PAI-1: Plasminogen activator inhibitor-1, DMN: dimethylnitrosamine, NOS: Nitric oxide synthase, t- PA: tissue plasminogen activator. NO: nitric oxide, HSCs: hepatic stellate cells, LPS: lipopolysaccharides.
\end{abstract}




\section{INTRODUCTION}

Hepatic fibrosis is a proliferative disease that might be initiated by a variety of factors including chronic viral hepatitis, alcohol abuse, druginduced lesions, heritable metabolic alterations, or exceptional functional disorders. Following liver injury of any etiology, hepatic stellate cells (HSC) become activated and transdifferentiate into proliferative, fibrogenic, and contractile myofibroblasts. The perpetuation of the activated phenotype involves key phenotypic responses mediated by increased cytokine effects and remodeling of extracellular matrix ${ }^{(\mathbf{1})}$. However, the immunological mechanisms underlying hepatic fibrosis due to chronic inflammation are not well defined.$^{(2)}$ Cytokines are synthesized and secreted in the liver mostly by kupffer cells and play a key role in inflammatory processes and immunological response related to liver diseases which are initiated by hepatocyte damage ${ }^{(3)}$. That type of signaling between different types of liver cells could produce contrary lesions. Loss of balance between these stimuli seems to be responsible for activation of the non-parenchymal cells, that result in accumulation of extracellular matrix proteins including collagen with liver cirrhosis as a clinical effect. ${ }^{(4)}$ The underlying mechanism of cytokine action is still unknown.

In the liver, TNF- $\alpha$ plays a central role in both proinflammatory and apoptotic response to endotoxin. That cytokine could transduce its signal by binding to one of two cellular receptors type I (p55) and type II (p75). ${ }^{(5)}$ It is typically associated with acute phase reaction, oxidant stress and it is implicated in fibrogenesis. ${ }^{(6)}$

IL-6 production is readily stimulated by viral, bacterial infection, upon exposure to lipopolysaccharides (LPS) released by intestinal bacteria into the portal system and in response to tissue damage. (7) TNF- $\alpha$, in addition to other cytokines, can induce IL-6 biosynthesis. IL-6 acts as a costimulant that synergistically augments the mitogenic effects of IL1 and TNF- $\alpha$ on T helper cells. ${ }^{(8)}$ IL-6 might play a role in the cirrhotic transformation of the liver. Aldeguer et al. ${ }^{(9)}$, demonstrated a paracrine mechanism by which Kupffer cells regulate the regenerative capacity of the hepatocyte through IL-6 expression.

Liver cirrhosis is known to have abnormal fibrinolysis. The plasma PAI-1 activity was altered with the progression of hepatic fibrosis. As the localization of PAI-1 is not only in interstitial cells but also in hepatocytes, it was suggested that an intense relationship between PAI-1 and hepatic fibrosis existed. ${ }^{(\mathbf{1 0})}$

There is evidence that both hepatocytes and infiltrating hepatic $\mathrm{T}$ cells have inducible NOS (iNOS) activity. ${ }^{(11)}$ However, the role of NO in cirrhosis induced inflammation remains unclear.

$\mathrm{NO}$ is a potent biologic mediator produced by hepatocytes following exposure to cytokines and endotoxins as LPS. ${ }^{(12)}$ It potentially exerts antifibrotic activity by down regulation of connective tissue growth factor (CTGF). It has antithrombotic properties as well. ${ }^{(13)}$ Expression of the prothrombotic protein PAI-1 is 
known to be regulated by NO. ${ }^{(14)}$ The influence of $\mathrm{NO}$ on cytokine production is gaining increased attention. However, literature provides contradictory informations. Inhibitors of NOS have potent prophylactic activity or injurious effect in several animal models of inflammatory diseases. ${ }^{(15)}$ Therefore, it is of great interest to establish the role of cytokines and NOS activity in cirrhosis.

\section{AIM OF THE STUDY}

The present study aimed to evaluate the role of some proinflammatory and profibrogenic mediators implicated in the pathogenesis of endothelial dysfunction in cirrhotic liver namely TNF- $\alpha$ and IL- 6 , that would be correlated with the severity of liver cirrhosis and the level of PAI-1 antigen as a marker of fibrinolytic activity. In addition, a trial will be made to investigate the possible role of induction of NOS synthesis and the effect of NOS inhibitor (L-NAME).

\section{MATERIAL AND METHODS}

40 male Sprague Dawley rats $(350-400 \mathrm{~g})$ were housed in a controlled environment. Induction of cirrhosis: Hepatic injury and fibrosis were induced by intraperitoneal injection (IP) of dimethylnitrosamine (DMN), (Sigma) on the first 3 consecutive days of each week over a period of 21 days. DMN doses were adjusted weekly according to body weight (BW). The dose was $1 \mathrm{ul}$ (diluted 1: 100 with $0.15 \mathrm{M} \mathrm{NaCl}$ ) $/ 100 \mathrm{~g}$ body weight. Controls (10 rats) received $\mathrm{NaCl}$ on the same schedule as experimental animals. Two groups of cirrhotic rats were studied: 20 rats without ascites (between the $1^{\text {st }}$ and $2^{\text {nd }}$ week treatment) and 20 rats after ascites was developed ( $3^{\text {rd }}$ week). Cirrhosis was confirmed by histological examination and ascites was confirmed in 15 rats by visual examination at labaratomy. In the cirrhotic rats, the study was performed 9-11 days after last dose of DMN ${ }^{(16)}$. Nine rats died during induction. A group of cirrhotic rats without ascites (8 rats) and another group with ascites (8 rats) were treated during 7 days with $\mathrm{Ng}$ nitro-L-arginine methyl ester (L-NAME), (Sigma) at a dose of $1 \mathrm{mg} / \mathrm{kg} /$ day by gavage twice a day. The last dose of L-NAME was given 12 hour before sacrifice. ${ }^{(17)}$

Finally; the groups were classified as follows:

Group I: 10 normal rats as a control group.

Group II: 8 cirrhotic rats without ascites

Group III: 7 cirrhotic rats with ascites. Group IV: 8 cirrhotic rats without ascites received L-NAME.

Group V: 8 cirrhotic rats with ascites received L-NAME.

Blood samples were obtained from the abdominal aorta under ether anesthesia (at 8:00 AM). Serum and plasma were preserved at $-70^{\circ} \mathrm{C}$ until analysis.

Serum electrolytes; (sodium and potassium) were measured using flame photometer. (18) Serum creatinine, urea, albumin and bilirubin were estimated by colorimetric methods. ${ }^{(19)}$ Blood samples were collected in EDTA tubes containing aprotinine at $\mathrm{O}^{\circ} \mathrm{C}$, centrifuged at 
$1600 \mathrm{~g}$ for 15 minutes. Plasma was stored at $-70^{\circ} \mathrm{C}$ till assay.

Determination of plasma TNF- $\alpha^{(20)}$ and IL-6 : (21) $^{2}$

The kits for TNF- $\alpha$ and IL-6 were purchased from Diaclone Research Laboratories (France). They are a solid phase sandwich enzyme linked immunosorbent assay (ELISA). A monoclonal antibody specific for TNF- $\alpha$ and IL- 6 respectively has been coated on the wells of the microtiter strips provided. Samples including standards of known TNF- $\alpha$ and IL- 6 concentrations, control specimens and unknown were pipetted into the wells respectively. During the first incubation, the TNF- $\alpha$ and IL- 6 antigen and a biotinylated monoclonal antibody specific for both of them respectively were simultaneously incubated. After washing, the enzyme streptavidin-peroxidase was added. After incubation and washing to remove the entire unbound enzyme, a substrate solution was added to induce a colored reaction product. The intensity of that colored product was directly proportional to the concentration of TNF- $\alpha$ and IL- 6 present in the samples respectively.

\section{Determination of plasma PAI-1: ${ }^{(22)}$}

PAI-1 determination was done by enzyme immunoassay (EIA). The wells of polystyrene microplate strips have been coated with a monoclonal anti-PAI-1, which constitute the solid phase antibody. After incubation of the tested samples, PAI-1 if present in the sample or standard solution, would bind to the solid phase antibody. Subsequently, a monoclonal anti PAI1 which has been labeled with the enzyme horse-radish peroxidase (HRP) was added. With a positive reaction, that labeled antibody became bound to any solid-phase antibody/PAI-1 complex previously formed. The amount of color produced in the well was proportional to the amount of PAI-1 originally present in the sample or standard solution.

Determination of plasma nitric oxide metabolites (plasma total nitrite): (23)

The kit for total nitric oxide assay (ELISA) was purchased from R \& D systems (USA) based on the conversion of nitrate to nitrite. Since most of NO in plasma was oxidized to nitrite $\left(\mathrm{NO}_{2}\right)$ and nitrate $\left(\mathrm{NO}_{3}\right)$, the concentrations of these anions have been used as a quantitative measurement of NO production. The spectrophotometric measurement of $\left(\mathrm{NO}_{2}\right)$ was accomplished by using the Griess reaction that absorbs light at $540 \mathrm{~nm}$. Plasma was diluted 3 folds, ultrafiltered through a 10,000 molecular weight cut off filter (Sigma) to get rid of proteins. Stock standard equal to $1000 \mu \mathrm{mol} / \mathrm{l}$ was diluted to give a series of standards ranging from 12 to $100 \mu \mathrm{mol} / 1$.

Determination of hepatic NOS activity: ${ }^{(24)}$

The liver was homogenized in buffer A for determination of NOS activity using hemoglobin method. (24) Homogenates were prepared in buffer A containing $0.32 \mathrm{M}$ sucrose, $20 \mathrm{mM}$ $\mathrm{N}-2$ hydroxyethylpiperazine $-\mathrm{N}$ ' -2 ethanesulfonic acid ( $\mathrm{pH} 7.2), 0.5 \mu \mathrm{M}$ EDTA, $1 \mathrm{mM}$ dithiothreitol, and protease inhibitors (3 M leupeptin, $1 \mathrm{mM}$ phenylmethylsulfonyl fluoride, and $1 \mu \mathrm{M}$ pepstatin $\mathrm{A}$ ), using glass homogenizer. The cytosolic and particulate fractions were separated by 
centrifugation. ${ }^{(25)}$ Nitric oxide
production was measured in the
supernatant spectrophotometrically the oxidation of oxyhaemoglobin to met haemoglobin at $37^{\circ} \mathrm{C}$ in a reaction medium containing $50 \mathrm{mM}$ phosphate buffer, $1 \mathrm{mM} \mathrm{CaCl}$, $1 \mathrm{mM}$ L-arginine, $100 \mu \mathrm{M} \quad \mathrm{NADPH}, \quad 10 \mu \mathrm{M}$ dithiothreitol, $4 \mu \mathrm{M}$ superoxide dismutase, $0.1 \mu \mathrm{M}$ catalase, sample and $5 \quad \mu \mathrm{M}$ oxyhaemoglobin. Measurements were carried out using a reference cuvette in which all the reactants were added except the oxyhaemoglobin. The kinetics was followed at $577 \mathrm{~nm}\left(\varepsilon=11.2 \mathrm{mM}^{-1} \mathrm{~cm}^{-}\right.$ $\left.{ }^{1}\right)$ and the absorbance changes were expressed as nmol NO/min/mg protein. ${ }^{(24)}$ Protein was assayed by the method of Lowry et al. ${ }^{\text {(26) }}$, using bovine serum albumin as standard.

Determination of hepatic nitric oxide metabolites (hepatic total nitrite): ${ }^{(27)}$

Total nitrite levels which represent the sum of nitrite and nitrate levels were estimated in the supernatant of hepatic homogenate using Griess reaction after enzymatic conversion by nitrate reductase ${ }^{(27)}$. The results were expressed as $\mathrm{nmol} / \mathrm{mg}$ protein.

\section{Statistical analysis:}

Data analysis and tabulation were done using SPSS version 9 computer software. The statistical tests used were F (ANOVA) test for comparison between more than two group means, and Correlation Coefficient ( $r$ ) to find the strength of correlation between quantitative variables. Values of $p<$ 0.05 were considered statistically significant. Data were expressed as mean $\pm \mathrm{SD}$.

\section{RESULTS}

I- Some liver function tests and electrolytes (Table I):

1- Serum albumin:

A significant decline of serum albumin level was noticed in all cirrhotic groups as compared to control group. Also, it was significantly declined in group III versus group II. Significant elevation was noticed upon L-NAME administration i.e. group IV vs. group II and group V vs. group III.

2- Serum bilirubin:

Serum bilirubin was significantly elevated in cirrhotic rats with ascites as compared to control ones, i.e. group III and V vs. group I. In group $\mathrm{V}$, bilirubin was significantly lower compared to group III. In both cirrhotic groups with ascites III and V, bilirubin levels were significantly higher compared to non-ascitic groups II and IV respectively.

3- Serum $\mathrm{Na}^{+}$:

Compared to control group, there was significant elevation of serum $\mathrm{Na}^{+}$ level in group III and significant decline at group IV. There was no significant change at group II and V. Ascitic groups had higher serum $\mathrm{Na}^{+}$ levels (group III vs. II and group V vs. IV). On L-NAME administration, there was no significant change in comparing group IV to group II. However, serum $\mathrm{Na}^{+}$was significantly declined when comparing group $\mathrm{V}$ with group III.

4- Serum $K^{+}$:

Serum $\mathrm{K}^{+}$levels were insignificantly changed in comparing the studied groups with the control. 
However, it was significantly elevated as group V compared with group IV.

II- Plasma TNF- $\alpha$, IL-6 and PAI-1: (table II, Figure 1)

1- Plasma TNF- $\alpha$ :

Plasma TNF- $\alpha$ was found to be significantly elevated in all fibrotic groups even upon L-NAME administration. It was, also, significantly elevated in cirrhotic group with ascites with L-NAME relative to without i.e. group V vs. III.

\section{2- Plasma IL-6:}

It was found to be significantly elevated in fibrotic groups with ascites and upon L-NAME administration i.e. groups III, IV and V vs. I. Also, in cirrhotic group with ascites upon LNAME administration i.e. group V vs. III.

\section{3- Plasma PAI-1:}

It was found to be insignificantly changed except in cirrhotic group with ascites upon L-NAME administration, i.e. group $\mathrm{V}$ was significantly increased relative to group I.

III- Plasma nitrite and hepatic nitrite and nitric oxide synthase activity: (table III, Figure 2)

\section{1- Plasma nitrite:}

A significant increase of plasma nitrite levels were detected in groups II, III and V as compared to group I. Group IV was insignificantly changed. plasma nitrite levels were significantly elevated at ascitic groups; III and V as compared to nonascitic groups II and IV respectively. Upon L-NAME administration; plasma nitrite levels were significantly declined i.e. group IV vs. group II and group V vs. group III.

\section{2- Hepatic nitrite:}

It was found to be significantly elevated at cirrhotic groups II and III, while it was significantly declined upon L-NAME administration i.e. group IV and V relative to control and cirrhotic groups II and III respectively.

\section{3- Hepatic NOS activity:}

It was found to be significantly increased with hepatic fibrosis i.e. group II and III relative to control. It returned to control levels upon LNAME administration i.e. insignificantly changed. Group IV and $\mathrm{V}$ showed significant decrease against their fibrotic groups II and III respectively.

\section{Correlations:}

Among all studied cases; plasma levels of TNF- $\alpha$ were found to be positively correlated with plasma levels of IL-6 and PAI-1. Plasma IL-6 levels were positively correlated to PAI-1, moreover, Hepatic NOS activity was positively correlated to hepatic nitrite level (Table IV, Figure $3)$. In the control group, plasma levels of PAI-1 were negatively correlated to IL-6 and positively correlated to hepatic nitrite levels (Table V). While, in cirrhotic groups; both plasmaTNF$\alpha$ and IL- 6 were positively correlated to each other and to both hepatic NOS activity and nitrite levels (Table VI, Figure 4). 
Table I: Some liver function tests and electrolytes in all studied groups:

\begin{tabular}{|c|c|c|c|c|c|c|c|}
\hline $\begin{array}{l}\text { Group } \\
\text { Number }\end{array}$ & $\begin{array}{c}I \\
10\end{array}$ & $\begin{array}{l}\text { II } \\
8\end{array}$ & $\begin{array}{c}\text { III } \\
7\end{array}$ & $\begin{array}{c}\text { IV } \\
8\end{array}$ & $\begin{array}{l}\text { V } \\
8\end{array}$ & $\begin{array}{c}\text { F test } \\
\text { P value }\end{array}$ & Scheff \\
\hline Serum & $4.73 \pm$ & $3.41 \pm$ & $2.72 \pm$ & $3.89 \pm$ & $3.65 \pm$ & 196.94* & $1 \# 2,3,4,5$ \\
\hline Albumin $(\mathrm{g} / \mathrm{dl})$ & 0.08 & 0.13 & 0.08 & 0.19 & 0.22 & 0.001 & $\begin{array}{l}2 \# 3,4 \\
3 \# 4,5\end{array}$ \\
\hline Serum & $0.71 \pm$ & $1.67 \pm$ & $6.67 \pm$ & $1.16 \pm$ & $3.27 \pm$ & $104.59 *$ & $1 \# 3,5$ \\
\hline $\begin{array}{l}\text { Bilirubin } \\
(\mathrm{mg} / \mathrm{dl})\end{array}$ & 0.08 & 0.15 & 1.17 & 0.28 & 0.95 & 0.0001 & $\begin{array}{c}2 \# 3,5 \\
3 \# 4,5 \\
4 \# 5\end{array}$ \\
\hline $\begin{array}{c}\operatorname{Serum~Na}^{+} \\
(\mathrm{mEq} / \mathrm{l})\end{array}$ & $\begin{array}{r}136.5 \\
\pm 1.58\end{array}$ & $\begin{array}{c}134.5 \pm \\
1.6\end{array}$ & $\begin{array}{l}145.71 \\
\pm 2.69\end{array}$ & $\begin{array}{c}132 \pm \\
3.89\end{array}$ & $\begin{array}{l}136.13 \\
\pm 1.46\end{array}$ & $\begin{array}{l}34.59 * \\
0.0001\end{array}$ & $\begin{array}{c}1 \# 3,4 \\
2 \# 3 \\
3 \# 4,5 \\
4 \# 5\end{array}$ \\
\hline $\begin{array}{c}\text { Serum } \mathrm{K}^{+} \\
(\mathrm{mEq} / \mathrm{l})\end{array}$ & $\begin{array}{c}4.16 \pm \\
0.21 \\
\end{array}$ & $\begin{array}{c}4.27 \pm \\
0.13 \\
\end{array}$ & $\begin{array}{c}4.22 \pm \\
0.07 \\
\end{array}$ & $\begin{array}{c}3.95 \pm \\
0.35 \\
\end{array}$ & $\begin{array}{c}4.38 \pm \\
0.22 \\
\end{array}$ & $\begin{array}{l}4.09 * \\
0.008\end{array}$ & $4 \# 5$ \\
\hline
\end{tabular}

* Significant at $\mathrm{p}<0.05$ level.

Table II: Plasma TNF- $\alpha$, IL-6 and PAI-1 in the all studied groups:

\begin{tabular}{|c|c|c|c|c|c|c|c|}
\hline $\begin{array}{c}\text { Group } \\
\text { Numbe } \\
\text { r }\end{array}$ & $\begin{array}{c}I \\
10\end{array}$ & $\begin{array}{l}\text { II } \\
8\end{array}$ & $\begin{array}{c}\text { III } \\
7\end{array}$ & $\begin{array}{c}\text { IV } \\
8\end{array}$ & $\begin{array}{l}\text { V } \\
8\end{array}$ & $\begin{array}{c}\text { F test } \\
\text { P value }\end{array}$ & Scheff \\
\hline $\begin{array}{l}\text { Plasma } \\
\text { TNF- } \alpha \\
\text { pg/ml }\end{array}$ & $\begin{array}{c}3.35 \pm \\
1.25\end{array}$ & $\begin{array}{c}29.19 \pm \\
12.09\end{array}$ & $\begin{array}{c}36.24 \pm \\
10.57\end{array}$ & $\begin{array}{c}41.13 \pm \\
15.72\end{array}$ & $\begin{array}{c}57.84 \pm \\
19.95\end{array}$ & $\begin{array}{l}20.84 * \\
0.0001\end{array}$ & $\begin{array}{c}1 \# 2,3,4,5 \\
2 \# 5 \\
3 \# 5 \\
4 \# 5\end{array}$ \\
\hline $\begin{array}{c}\text { Plasma } \\
\text { IL-6 } \\
\text { pg/ml }\end{array}$ & $\begin{array}{c}5.78 \pm \\
1.66\end{array}$ & $\begin{array}{c}12.24 \pm \\
3.05\end{array}$ & $\begin{array}{c}66.14 \pm \\
32.56\end{array}$ & $\begin{array}{c}32.77 \pm \\
17.59\end{array}$ & $\begin{array}{c}104.94 \pm \\
48.13\end{array}$ & $\begin{array}{l}20.53 * \\
0.0001\end{array}$ & $\begin{array}{c}1 \# 3,4,5 \\
2 \# 5 \\
3 \# 4,5 \\
4 \# 5\end{array}$ \\
\hline $\begin{array}{c}\text { PlasmaP } \\
\text { AI-1 } \\
\mathrm{pg} / \mathrm{ml}\end{array}$ & $\begin{array}{l}29.11 \\
\pm 1.46\end{array}$ & $\begin{array}{c}35.21 \pm \\
7.32\end{array}$ & $\begin{array}{c}34.33 \pm \\
11.2\end{array}$ & $\begin{array}{c}34.99 \pm \\
10.39\end{array}$ & $\begin{array}{c}38.86 \pm \\
8.75\end{array}$ & $\begin{array}{l}1.65 \\
\mathrm{NS}\end{array}$ & $1 \# 5$ \\
\hline
\end{tabular}

* Significant at $\mathrm{p}<0.05$ level. 
Table III: Plasma nitrites and hepatic nitrites and nitric oxide synthase activity in the all studied groups:

\begin{tabular}{|c|c|c|c|c|c|c|c|}
\hline Group & I & II & III & IV & V & F test & Scheff \\
Number & 10 & 8 & 7 & 8 & 8 & P value & \\
\hline Plasma & $8.68 \pm$ & $14.48 \pm$ & $17.39 \pm$ & $9.76 \pm$ & $12.36 \pm$ & $106.29^{*}$ & $1 \# 2,3,5$ \\
nitrite & 0.6 & 1.28 & 1.36 & 0.67 & 0.84 & 0.0001 & $\begin{array}{c}2 \# 3,4,5 \\
\text { (mmol/l) }\end{array}$ \\
& & & & & & & $3 \# 4,5$ \\
& & & & & & $4 \# 5$ \\
\hline $\begin{array}{c}\text { Hepatic } \\
\text { nitrite }\end{array}$ & $299.12 \pm$ & $330.53 \pm$ & $346.54 \pm$ & $254.19 \pm$ & $253.98 \pm$ & $15.1 *$ & $1 \# 2,3,4,5$ \\
(nmol/mg & & 20.27 & 38.81 & 30.47 & 24.5 & 0.0001 & $2 \# 4,5$ \\
protein) & & & & & & & $3 \# 4,5$ \\
\hline $\begin{array}{c}\text { Hepatic } \\
\text { NOS } \\
\text { (nmol/min } \\
/ \mathrm{mg}\end{array}$ & $0.93 \pm$ & $3.54 \pm$ & $4.99 \pm$ & $2.17 \pm$ & $2.7 \pm$ & $10.88^{*}$ & $1 \# 2,3$ \\
protein) & & 1.33 & 1.33 & 0.83 & 0.55 & 0.0001 & $2 \# 3,4$ \\
& & & & & & $3 \# 4,5$ \\
\hline
\end{tabular}

* Significant at $\mathrm{p}<0.05$ level.

Table IV: Correlation studies between different parameters among all studied groups (n=41 rats) :

\begin{tabular}{|c|c|c|c|c|c|}
\hline & TNF- $\alpha$ & IL-6 & PAI-1 & NOS & Hepatic nitrite \\
\hline TNF- $\alpha$ & & & & & \\
$\mathrm{r}$ & 1 & $\begin{array}{c}0.478^{* *} \\
\text { p }\end{array}$ & $\begin{array}{c}0.336^{*} \\
0.002\end{array}$ & $\begin{array}{c}0.172 \\
0.032\end{array}$ & $\begin{array}{c}-0.258 \\
0.103\end{array}$ \\
\hline IL-6 & & & & & \\
$\mathrm{r}$ & $0.478^{*}$ & 1 & $0.407 * *$ & 0.172 & -0.296 \\
$\mathrm{p}$ & 0.002 & & 0.008 & 0.283 & 0.060 \\
\hline PAI-1 & & & & & \\
$\mathrm{r}$ & $0.336^{*}$ & $0.407^{* *}$ & 1 & -0.046 & -0.056 \\
$\mathrm{p}$ & 0.032 & 0.008 & & 0.777 & 0.729 \\
\hline Hepatic NOS & & & & & \\
$\mathrm{r}$ & 0.172 & 0.172 & -0.046 & 1 & $0.346^{*}$ \\
$\mathrm{p}$ & 0.282 & 0.283 & 0.777 & & 0.027 \\
\hline Hepatic nitrite & & & & & \\
$\mathrm{r}$ & -0.258 & -0.296 & -0.056 & $0.346^{*}$ & 1 \\
\hline
\end{tabular}

* Significant at $\mathrm{p}<0.05$ level. 
Table V: correlation studies between plasma PAI-1 and other parameters among control group ( $n=10$ rats):

\begin{tabular}{|c|c|c|c|c|c|}
\hline & TNF- & IL-6 & PAI-1 & NOS & Hepatic nitrite \\
\hline Plasma PAI-1 & & & & & \\
r & -0.57 & $-0.653^{*}$ & 1 & 0.013 & $0.801^{* *}$ \\
p & 0.086 & 0.041 & & 0.973 & 0.005 \\
\hline
\end{tabular}

* Significant at $\mathrm{p}<0.05$ level.

Table VI: Correlation studies between plasma TNF- $\alpha$ and IL-6 and different parameters among cirrhotic groups $(\mathrm{n}=\mathbf{2 5}$ rats):

\begin{tabular}{|c|c|c|c|c|c|}
\hline & TNF- $\alpha$ & IL-6 & PAI-1 & Hepatic NOS & Hepatic nitrite \\
\hline TNF- $\alpha$ & & & & & \\
$\mathrm{r}$ & 1 & $0.496^{*}$ & 0.297 & $0.605^{* *}$ & $0.473^{*}$ \\
$\mathrm{p}$ & & 0.012 & 0.15 & 0.001 & 0.017 \\
\hline IL-6 & & & & & \\
$\mathrm{r}$ & $0.496^{*}$ & 1 & 0.365 & $0.568^{* *}$ & 0.369 \\
$\mathrm{p}$ & 0.012 & & 0.073 & 0.003 & 0.069 \\
\hline
\end{tabular}

* Significant at $\mathrm{p}<0.05$ level.

$* *$ Significant at $\mathrm{p}<0.01$ level. 


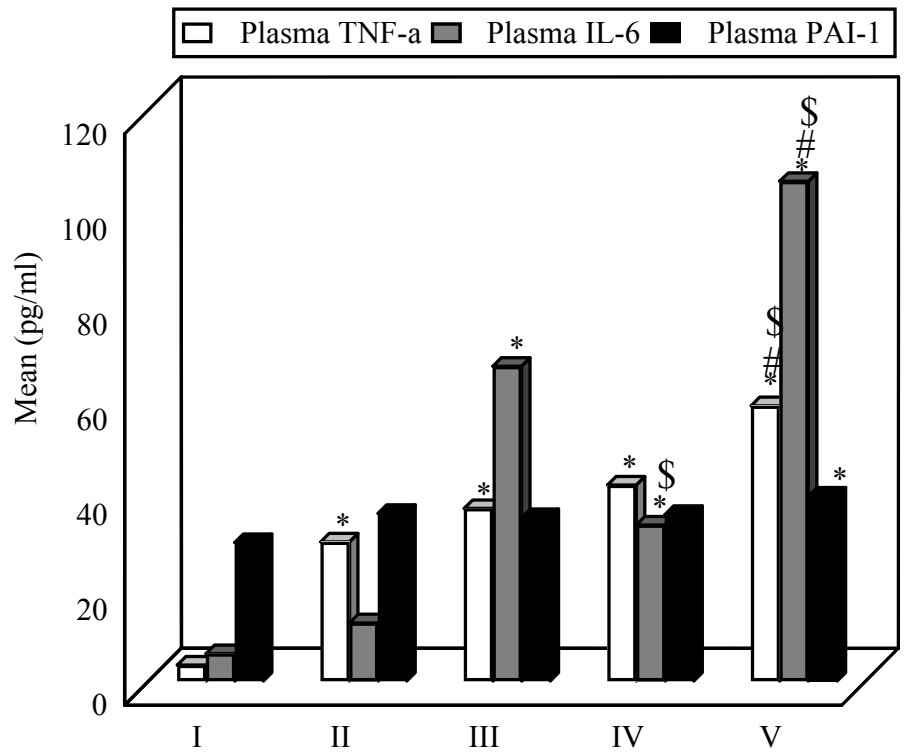

Figure (1): Plasma TNF-a, IL-6 and PAI-1 in the studied groups. * : Significant compared to group I (control).

\# : Significant compared to group II.

\$ : Significant compared to group III.

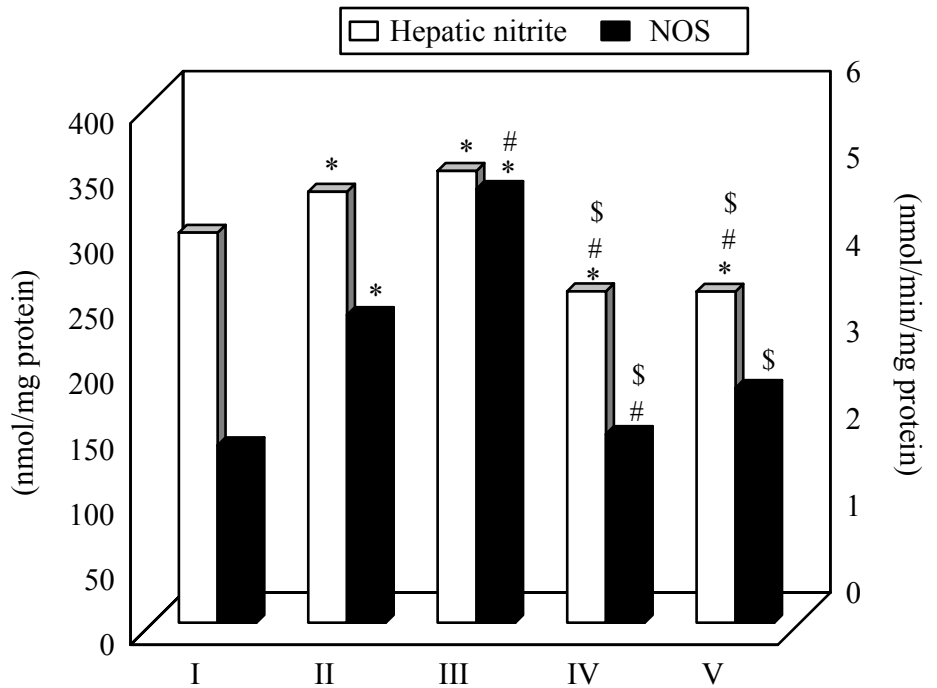

Figure (2): Hepatic nitrite and nitric oxide synthase activity in the studied groups. 

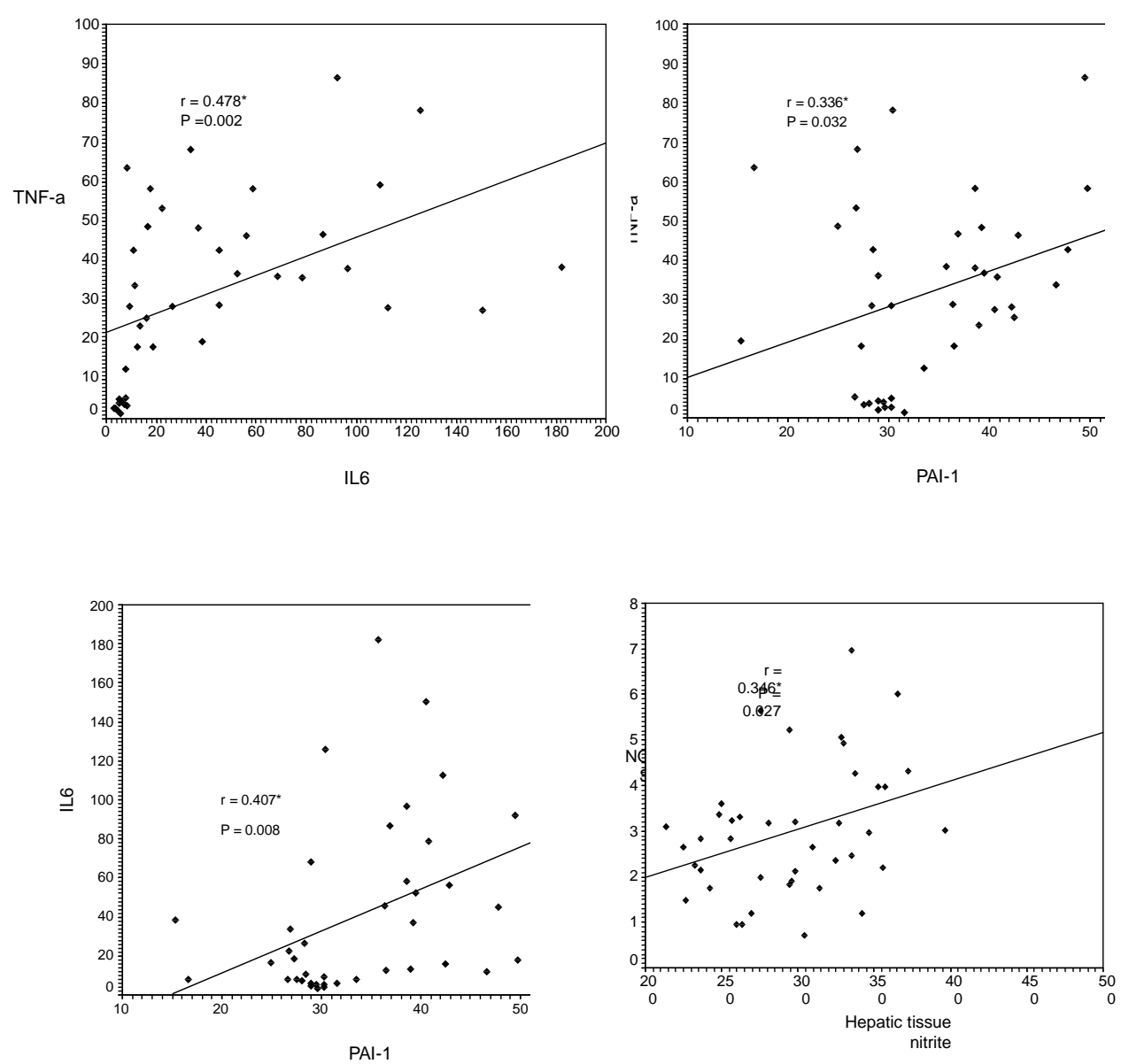

Fig. 3: Correlation between different parameters among all studied groups. 

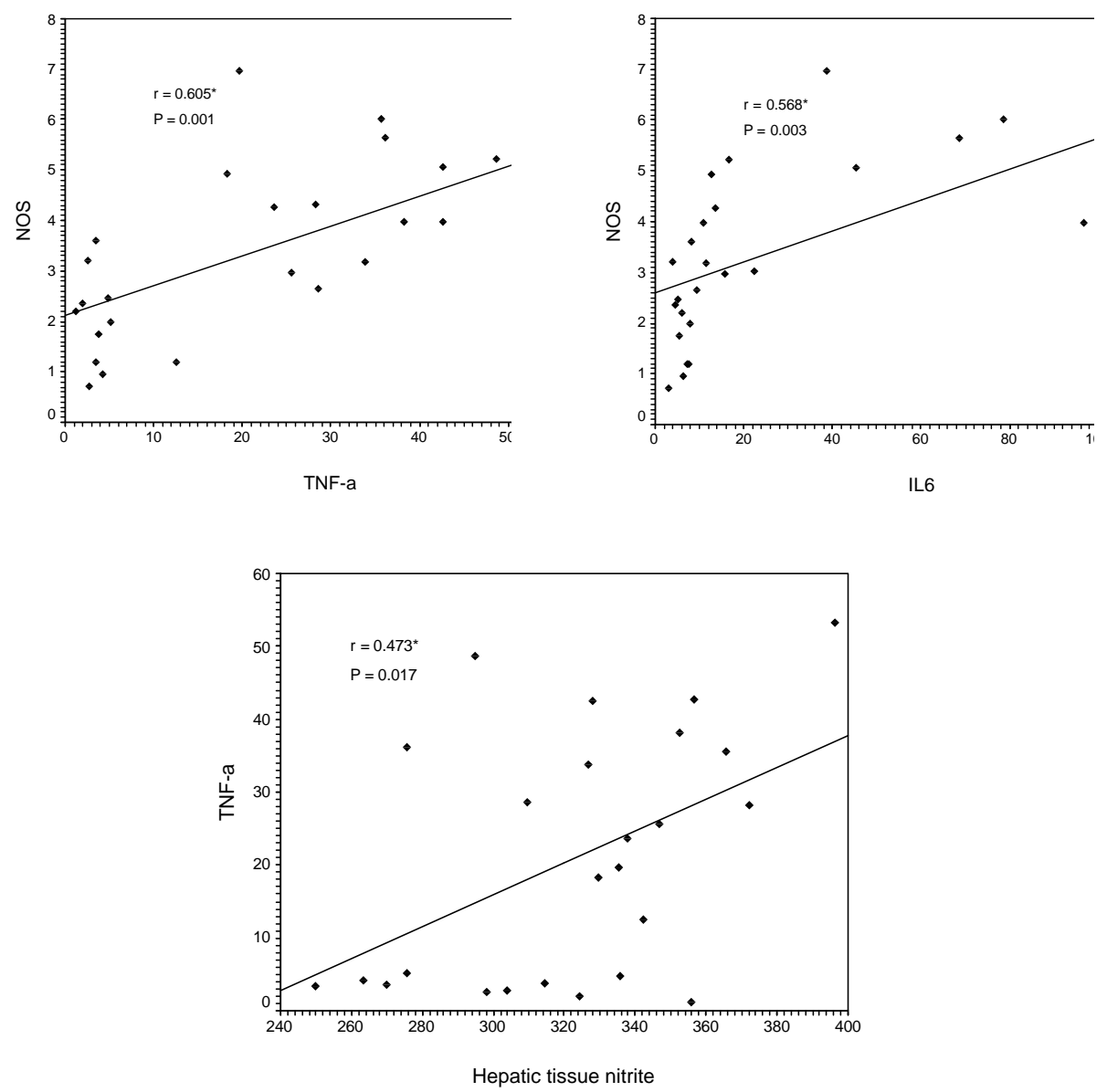

Fig. 4: Correlation between different parameters among cirrhotic groups.

\section{DISCUSSION}

Liver cirrhosis is characterized by hepatic dysfunction with extensive accumulation of fibrous tissue in the liver. ${ }^{\text {(28) }}$ It is a wounding and repairing response, and could be initiated in different ways. It has been shown that hepatic stellate cells (HSCs) were the main source of extracellular matrix in fibrosis. Certain cytokines could modulate the proliferation and collagen synthesis of HSCs. ${ }^{(29)}$

In accordance with many investigations, ${ }^{(6,7,30)}$ the present study showed a highly significant increase in the level of plasma TNF- $\alpha$ concentration in cirrhotic rats compared to controls. TNF- $\alpha$ is a 
mediator of inflammation and cellular immune response. In liver cirrhosis, impaired clearance of endotoxin together with increased secretion of TNF- $\alpha$ by extrahepatic macrophages might play an important role in the progression of hepatic and renal disturbances. ${ }^{(31)}$ High levels of TNF- $\alpha$ could suggest the presence of immunological mechanism, including activation of TNF system. (32) However, another study showed that TNF- $\alpha$ is not strongly implicated in fibrogenesis, as it stimulates interstitial collagenase, and it selectively augments matrix degradation. ${ }^{(33)}$ Simeonova et al. ${ }^{(34)}$, indicated that TNF- $\alpha$ is responsible for regulating products that induce both inflammation and fibrosis. TNF$\alpha$ increases proliferation and collagen synthesis of HSCs.

In the current study, a statistically significant increase in the plasma levels of IL- 6 were present in cirrhotic rats compared to controls. These results were in accordance with many previous studies, ${ }^{(35,36)}$ and in contrast to a study conducted by Yamashiki et al. ${ }^{(37)}$, in which the plasma levels of IL-6 were similar in both cases with biliary cirrhosis and controls. The present results showed significantly higher levels of IL-6 in advanced stages of liver dysfunction as well i.e. with ascites (group III and V) compared to early stages of the disease i.e. without ascites (group II and IV respectively). Such finding was in agreement with several reports indicating that the plasma levels of IL6 were higher with worsening of liver functions. ${ }^{(38,39)}$ This could be explained by the fact that not only the liver represents an important site of synthesis of cytokines, but, also, it is a major clearance organ for several extrahepatically produced cytokines. So, increased endogenous cytokines might be a consequence of impaired clearance due to hepatocyte dysfunction and/or presence of portosystemic collaterals. ${ }^{(40)}$

Elevated cytokines as a cause or as a consequence of chronic liver diseases, play an important role in the cirrhotic transformation of the liver. Intrahepatically produced cytokines act in an autocrine and/or paracrine manner with other hepatic cells such as fibroblasts. ${ }^{(41)}$ Moreover, inflammatory cytokines such as IL-6 regulate metalloproteinases and their specific inhibitors, which were believed to play a role in the extracellular matrix metabolism and fibrogenesis. ${ }^{(\mathbf{4 2})}$ So, in liver cirrhosis, there were both increased production and decreased metabolism of TNF- $\alpha$ and IL-6. A significant correlation was observed between TNF- $\alpha$ and IL6 in all studied rats and in fibrotic groups. Such result was consistent with that found by Zhang et al. ${ }^{(43)}$. These cytokines work in concert in many ways; TNF- $\alpha$ stimulates IL-6 production, and IL-6 augments the effect of TNF- $\alpha$ on T helper cells. A specific pattern of altered cytokines IL-6 and TNF- $\alpha$ gene expression in advanced stages of severe liver diseases, was reported to be characteristic for them. ${ }^{(44)}$

In the present study, there was no statistically significant difference between plasma PAI-1 antigen levels in cirrhotic rats and controls except the fibrotic group with L-NAME. That finding was consistent with that reported by Hayashi et al. ${ }^{(45)}$ who 
suggested that if any increased PAI-1 release, it was probably an indirect response to an increase of t-PA or as a result of impaired hepatic clearance. Patients with liver cirrhosis have hyperfibrinolysis, the mechanism is mainly due to increased concentrations of t-PA relative to normal activity PAI-1 levels. (46) Normal activity of PAI-1 was demonstrated by many previous studies. ${ }^{(46,47)}$ Moreover, Li et al. ${ }^{(48)}$, showed a decrease in plasma PAI-1 activity with progression of hepatic fibrosis, despite a significant increase in the level of PAI-1 antigen. PAI-1 might contribute to development of fibrosis after chemical or ionizing injury ${ }^{(49)}$; which could explain their significantly increased levels in cirrhotic rats with NO inhibition.

The present data showed positive correlation between plasma PAI-1 and both TNF- $\alpha$ and IL- 6 levels. These results were in agreement with that found by Zhang et al (50) who suggested that high levels of TNF- $\alpha$ and IL-6 might contribute to hypofibrinolysis and intravascular coagulation in patients with liver cirrhosis.

An enhanced production of $\mathrm{NO}$ in the studied cirrhotic groups is an important factor contributing to the renal $\mathrm{Na}^{+}$and water retention. The plasma cytokines TNF- $\alpha$ and IL- 6 are positively correlated with hepatic NOS in cirrhotic groups. They activate iNOS expression in the liver through the transcription factor nuclear factor Kappa B. ${ }^{(51)}$ Hepatic iNOS expression functions as an adaptive response to minimize inflammatory injury. Therefore, NOS inhibitors increased hepatic damage. ${ }^{(52)}$

NO exerts its protective effect through its ability to prevent intravascular thrombosis by inhibiting platelet adhesion and neutralizing toxic oxygen radicals. Also, by blocking TNF- $\alpha$ induced apoptosis and hepatotoxicity, in part by a thioldependent inhibition of caspase-3 like protease activity. ${ }^{(53)}$ It is suggested that inhibitors of NOS activity leads to a decrease in the $\mathrm{NO} / \mathrm{ROS}$ ratio thereby favoring the development of fibrosis. In addition, they block tonic inhibitory action of constitutively produced NO on TNF- $\alpha$ production ${ }^{(54)}$

NO affects PAI-1 expression in endothelial cells. Endogenously generated NO in a pathway induced by TNF- $\alpha$ activates mitogen activated protein kinases (MAPKs) and induces upregulation of PAI-1. ${ }^{(55)}$ Vasoprotective function of endothelial cells is associated with biosynthesis and release of $\mathrm{NO}$ and t-PA. These endothelial mediators calm down activated platelets and leukocytes, prevent occurrence of thrombotic events and promote thrombolysis. Endothelial dysfunction in cirrhosis is associated with suppression in release of t-PA and deleterious discharge of PAI-1. ${ }^{(56)}$

It could be concluded that measurement of plasma cytokines: TNF- $\alpha$ and IL-6 levels as clinical immunological tests are highly useful. They might be used as indicators for the progression of fibrosis in cirrhotic patients. They were correlated with hepatic NOS activity which functions as an adaptive response to minimize inflammatory injury. PAI-1 increased at severe fibrotic liver with other 
injury. Further studies are needed to evaluate the use of inhibitors of profibrogenic cytokines and precursors of NOS expression as novel therapeutic agents in controlling fibrosis.

\section{REFERENCES}

1. Borkham-Kamphorst E, Herrmann J, Stoll D, Treptau J, Gressner A M, Weiskirchen R. (2004): Dominant-negative soluble PDGF- $\beta$ receptor inhibits hepatic stellate cell activation and attenuates liver fibrosis. Lab. Invest., 84: 766-77.

2. Luckey SW, Petersen DR. (2001): Activation of kupffer cells during the course of carbon tetrachloride induced liver injury and fibrosis in rats. Exp. Mol. Pathol., 71(3): 226-40.

3. Bataller R, Brenner DA. (2005): Liver fibrosis. J. Clin. Invest., 115(4): 1100-9.

4. Flisiak R. (1999): Cytokines in the pathogenesis of liver fibrosis. Przegl. Lek., 56(9): 604-7.

5. Crespo J, Cayon A, FernandezGil P, Hernandez-Guerra M, Mayorga M, Dominguez- Diez A, Fernandez-Escalante JC, Pons- Romero F. (2001): Gene expression of tumor necrosis factor- $\alpha$ and TNF- $\alpha$ receptors; p55 and p75, in nonalcoholic steatohepatitis patients. Hepatology, 34(6): 1158-63.

6. Zhang HY, Han DW, Wang XG, Zhao YC, Zhou X, Zhao HZ. (2005): Experimental study on the role of endotoxin in the development of hepatopulmonary syndrome. World J.

Gastroenterol., 11(4): 567-72.

7. Zhuang L, Ma Z, Liu T. (2000):

Effect of anti-endotoxin therapy on vasoactive substances in decompensated liver cirrhosis. Zhonghua Gan Zang Bing Za Zhi., 8(2): 94-5.

8. Galun E, Axelrod JH. (2002): The role of cytokines in liver failure and regeneration. Biochim. Biophys. Acta., 159(3): 345-58.

9. Aldeguer $\mathbf{X}$, Debonera $\mathbf{F}$, Shaked A, Krasinkas AM, Gelman AE,Que x, Zamir GA, Hiroyasu S, Kovalovish KK, Taub R, Olthoff KM. (2002): Interleukin-6 from intrahepatic cells of bone marrow origin is required for normal murine liver regeneration. Hepatology, 35(1): 40-8.

10. Li Q, Qin C, Lao P. (2000): Expression and plasma activity of plasminogen activator inhibitor-1 in fibrotic liver tissues. Zhonghua Gan Zang Bing Za Zhi., 8(4):20911.

11. Wang H, Chen XP, Qui FZ,. (2004): Increased hepatic expression of nitric oxide synthase type II in cirrhotic rats. World J. Gastroenterol., 10(13): 1923-7.

12. Wei CL, Khoo HE, Lee KH, Hon WM. (2002): Differential expression and localization of nitric oxide synthases in cirrhotic livers of bile duct ligated rats. Nitric Oxide, 7(2): 91-102.

13. Keil A, Blom IF, Goldschmeding R, Rupprecht HD. (2002): Nitric oxide down regulates connective tissue 
growth factor in rat mesangial cells. Kid. Int., 62(2): 401-11.

14. Fernandez-Varo G, Rose J, Morales-Ruiz M, CejudoMartin P, Arroyo V, Sole M, rivera $\mathbf{F}$, Rodes $\mathbf{J}$, Jiminez $\mathbf{W}$. (2003): Nitric oxide synthase dependent vascular remodeling and circulatory dysfunction in cirrhosis. Am. J. Pathol., 162(6): 1985-93.

15. Bhimani EK, Serracino-Inglott F, Sarela AI, Batten JJ, Mathie RT. (2003): Hepatic and mesenteric nitric oxide synthase expression in a rat model of $\mathrm{CCl}_{4}$ induced cirrhosis. J. Surg. Res., 11(1): 172-8.

16. Leena A, Myeres JC, Kivirikko KI, Savolainen ER. (1987): Gene expression of types I, III and IV collagens in hepatic fibrosis induced by dimethylnitrosoamine in the rat. Biochem. J., 244: 75-9.

17. Martin PV, Gines $P$, Morris $K$, Tsai P, Schrier RW. (1995): Normalization of nitric oxide production corrects arterial vasodilatation and hyperdynamic circulation in cirrhotic rats. Gastroenterol., 109: 1624-30.

18. Proehl EC, Nelson WP. (1950): The flame photometer in determination of sodium and potassium. Am. J. Clin. Pathol., 20(9): 806-13.

19. Varley H, Gowenloch AH. (1998): Practical clinical biochemistry, volume 1, General topic and commoner tests. $6^{\text {th }}$ ed. London: Williams Heinemann Medical Books Ltd., pp., 350-67.

20. Khorutus A, Stahnke L. (1991): Circulating tumor necrosis factor- $\alpha$, IL- 1 and IL- 6 concentrations in chronic alcoholic patients. Hepatology, 13(2): 267-76.

21. Chick VB, Furst DE. (1994): Analysis of elevated serum interleukin-6 levels in rheumatoid arthritis: correlation with erythrocyte sedimentation rate or C-reactive protein. J. Lab. Clin. Med., 123(5): 721-7.

22. Declerck PJ, Alessi MC, Verstreken M, Kruithof EK, Juhnan Vague I, Collen D. (1988): Measurement of plasminogen activator inhibitor1(PAI-1) in biological fluids with a murine monoclonal antibody based enzyme linked immunosorbent assay. Blood, 71: 220-5.

23. Makelo S. (1997): Technical Brief: Nitric oxide determinations. Clin. Chem., 43(12): 2418-22.

24. Murphy ME, Noack E. (1994): Nitric oxide assay using hemoglobin method. Methods Enzymol., 233: 240-50.

25. Bush PA, Gonzalez NE, Griscavage JM, Ignaro LJ. (1992): Nitric oxide synthase from cerebellum catalyzes the formation of equimolar quantities of nitric oxide and citrullin from L-arginine. Biochem. Biophys. Res. Commun., 185: 960.

26. Lowery OH, Roebrough NJ, Farr AL, Randal RJ. (1951): Protein measurement with the folin phenol reagent. J. Biol. Chem., 193: 265-75.

27. Paglia DE, Valentine WN. (1967): Studies on the quantitative and qualitative characterization of erythrocyte 
glutathione peroxidase. J. Lab. Clin. Med., 70: 158-69.

28. Kim WH, Matsumoto $K$, Bessho K, Nakamura T. (2005): Growth inhibition and apoptosis in liver myofibroblasts promoted by hepatocyte growth factor leads to resolution from liver cirrhosis. Am. J. Pathol., 166(4):1017-28

29. Chensue SW, Warmigton KS, Ruth JH, Lincoln P, Kunkel SL. (2001): Cytokine responses during mycobacterial and schistosomal antigen-induced granuloma formation. Am. J. Pathol., 158(4): 298-306.

30. Countink HM, Acosta LP, Manalo DL, Langdon GC, Laenstra T, Solomon J, Kurtis JD. (2005): Nutritional status and serum cytokine profiles in children, adolescents and young adults with Schistooma japonicum associated hepatic fibrosis. J. Infect. Dis., 192(3): 528-36.

31. Nakatani Y, Fukui H, Kitano H, Nagamoto I, Tsujimoto $\mathbf{T}$, Kuriyama S, Kikuchi F, Happon k, Tsujii T. (2001): Endotoxin clearance and its relation to hepatic and renal disturbances in rats with liver cirrhosis. Liver, 219(1): 64-70.

32. Baveja R, Keller S, Yokoyama Y, Sonin N, Clemens MG, Zhang JX. (2002): Lipopolysaccharide induced imbalanced expression of hepatic vascular stress genes in cirrhosis: possible mechanism of increased susceptibility to endotoxemia. Shock, 17(4): 316-21.

33. Hernandez S, Munoz I, Sanchez A. (1997): Tumor necrosis factor alpha inhibits collagen gene expression and stimulate interstitial collagenase in rat stellate cells. Gastroenterol., 113: 625-40.

34. Simeonova PP, Galluci RM, Hulderman T, Wilson R, Kommenini C, Ran M, Luster MI. (2001): The role of tumor necrosis factor alpha in liver toxicity, inflammation and fibrosis induced by carbon tetrachloride. Toxicol. Appl. Phamacol., 177(2): 112-20.

35. Genesea J, Gonzalez A, Segura R, Catalan R, Marti R, Varela E, Cadelina G, Martinez $M$, Lopez-Talavera Jc, Esteban R, Groszmann RJ, Guardia J. (2000): Interleukin-6, nitric oxide, and the clinical and hemodynamic alterations of patients with liver cirrhosis. Am. J. Gastroenterol., 95(1): 323-4.

36. Swaitkowka SR, Bakowka A. (2004): Serum IL-6 in patients with alcoholic liver disease. Pol. Merkuriusz Lek., 17(99):255-9.

37. Yamachiki M, Kosaka Y, Nishimura A, Watanab S, Nomoto M, Ichida F. (1998): Analysis of serum cytokine levels in primary biliary cirrhosis patients and healthy adults. J. Clin. Lab. Anal., 12(2): 77-82.

38. Such J, Hillebrand DJ, Guarner C, Berk L, Zapater P, Westengard J, Peralta C, Soriano G, Pappas J, Runyon BA. (2001): Tumor necrosis factor-alpha, interleukin 6 and nitric oxide in sterile ascitic fluid and serum from patients with cirrhosis who subsequently 
develop ascitic fluid infection. Dig. Dis. Sci., 46(11): 2360-6.

39. Kayano K, Okita K. (2000): Does IL-6 regulate liver fibrosis/ cirrhosis directly and indirectly? J. Gastroenterol., 35(3): 250-1.

40. Solis Herruzo JA, de la Torre P, Diaz Sanjuan T, Garcia Ruiz I, Munz Yague T. (2005): IL-6 and extracellular matrix remodeling. Rev. Esp. Enferm. Dig., 97(8): 575-95.

41. Giron-Gonzalez JA, MartinezSierra C, Rodriguez-Ramos C, Macias MA, Rendon P, Diaz F. (2004): Implication of inflammation related cytokines in the natural history of liver cirrhosis. Liver Int., 24(5): 43745.

42. Banal MB, Kovalovich $K$, Gupta R, Li W, Agarwal A, Safadi R, Fiel MI. (2005): IL-6 protects hepatocytes from carbon tetrachloride mediated necrosis and apoptosis in mice by reducing metalloprotienase expression. J. Hepatol., 42(4): 548-56.

43. Zhang HY, Yu JP, Liu D, Huang YH, Chen ZX, WangXZ (2004): Effects of cytokine on carbon tetrachloride induced hepatic fibrogenesis in rats. World J. Gastroenterol., 10(1): 77-81.

44. Mammaev SN, Lukina EA, Shul'pekova IuO, Levina AA, Ivashkin VT. (2001): Cytokine regulation of liver inflammation and fibrosis during chronic hepatic diseases. Klin. Lab. Diagn., (12): 37-40.

45. Hayashi $T$, Kamogawa A, Ro S, Yamaguchi Y, Takahashi Y, Murayama M. (1998): Plasma from patients with cirrhosis increases tissue plasminogen activator release from vascular endothelial cells in vitro. Liver, 18(3): 186-90.

46. Matsurra R, oma M, Maeda Y, Kasakura S. (1995): Studies on the mechanism of hyperfibrinolysis in liver cirrhosis: changes of plasma tPA, PAI-1 and active PAI-1 levels in liver cirrhosis. Rinsho Byori 43(12): 1256-60.

47. Wu XR, Lu MH, Wang Q, Shi SS, Guo WD. (2004): The plasma levels of TGF beta and the protein expression of urokinase plasminogen activator and PAI-1 in liver of patients with different grades of hepatic fibrosis. Zhonghua Gan Zang Bing Za Zhi., 12(7): 400-2.

48. Inuzuka $S$, Ueno $T$, Torimura T, Tamaki S, Sugawara $\mathbf{H}$, Akata R, Kusaba N, Sata M, Tanikawa K. (1997): The significance of colocalization of plasminogen activator inhibitor-1 and vitronectin in hepatic fibrosis. Scand. J. Gastroenterol., 32(10): 1052-60.

49. Kaikita K, Fogo AB, Ma L, Schoenhard JA, Brown NJ, Varghan DE. (2001): Plasminogen activator inhibitor-1 deficiency prevents hypertension and vascular fibrosis in response to long- term nitric oxide synthase inhibition. Circulation, 104(7): 839-44.

50. Zhang LP, Takahara t, Yata $Y$, Furui K, Jin B, Kawada N, Watanable A. (1999): Increased expression of plasminogen activator and plasminogen 
activator inhibitor during liver fibrogenesis of rats: role of stellate cells. J. Hepatol., 31(4): 703-11.

51. Tang $X$, Zhou $D$, Kang $G$. (2001): Induction and kinetic characterization of nitric oxide synthase in hepatocytes. Zhonghua Gan Zang Bing Za Zhi., 9(3): 169-71.

52. Ferrini MG, Vernet D, Magie TR, Shahed A, Qian A, Rajfer J, Gonzalez-Cadavid NF. (2002): Antifibrotic role of inducible nitric oxide synthase. Nitric Oxide, 6(3): 283-94.

53. Wang JJ, Gao GW, Gao RZ, Liu CA, Ding XA, Yao ZX. (2004): Effects of tumor necrosis factor, endothelin and nitric oxide on hyperdynamic circulation of rat with acute and chronic portal hypertension. World J. Gastroenterol., 10(5): 689-93.
54. Conor TJ, O'Sullivan J, Nolan Y, Kelly JP. (2003): Inhibition of constitutive nitric oxide production increases the severity of lipopolysaccharide- induced sickness behaviour: a role for tumor necrosis factor alpha. Neuroimmuno-modulation, 10(6): 367-78.

55. Van de Casteele $M$, Onasta A, Roskams T, Desmet V, Nevens F, Fevery J. (2002): In vivo gene transfer of endothelial nitric oxide synthase decreases portal pressure in anaesthetized cirrhotic rats. Gut, 51(3): 440-5.

56. Swiatkowska $M$, CierniewskaCieslak A, Pawlowska Z, Cierniewski CS. (2000): Dual regulatory effects of nitric oxide on plasminogen activator inhibitor type 1 expression in endothelial cells. Eur. J. Biochem., 267(4): 1001-7.

$$
\begin{aligned}
& \text { مستويات بعض عوامل التليف بالبلازما و إنزيم مكون أكسيد النتريك فى } \\
& \text { الكبد المتليفة المستحثة تجريبيا فى الفئران }
\end{aligned}
$$

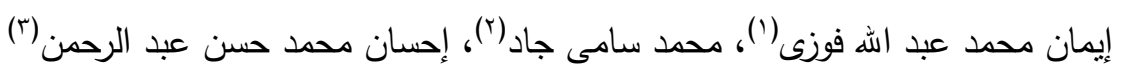

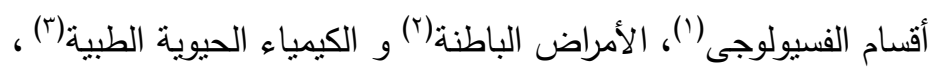

$$
\begin{aligned}
& \text { كلية الطب، جامعة الاسكندرية }
\end{aligned}
$$

مقدمة البحث: ينتج التليف الكبدى عن تنشيط الخلايا الكبدية نجمية الثكل والتى تتحور إلى خلايا ليفية

عضلية من حيث الثكل الظاهرى. هذه الخلايا لها القدرة على الانقسام وتصنيع كميات كبيرة من مكونات النسيج

الموجود خارج الخلية ومن ثم تؤدى إلى هذا التليف.

الغرض من البحث: دراسة المستويات بالبلازما لكل من عامل نآكل الورم-ألفا و إنترلوكين-7 كعوامل

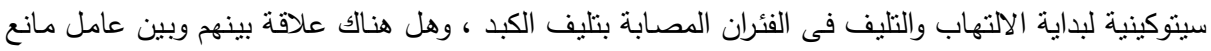


منشط البلازمينوجين ا كدلالة لنشاط نآكل التليف. وإضافة إلى ذلك، إيجاد علاقة بين هذه السيتوكينات و نثاط إنزيم مكون أكسيد النيتريك الكبدى.

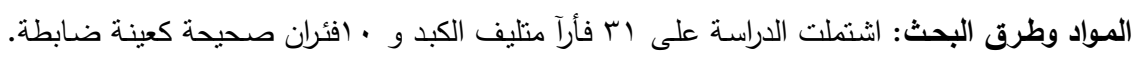

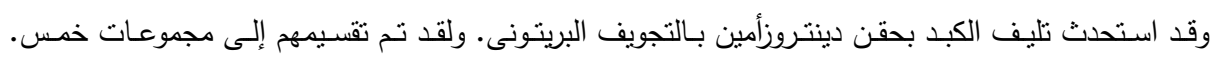

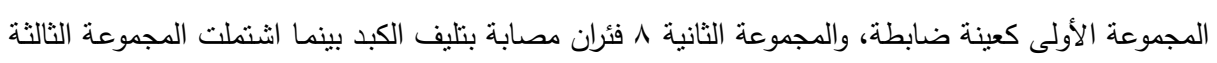

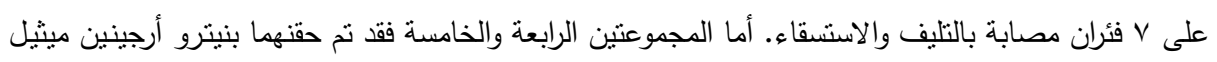

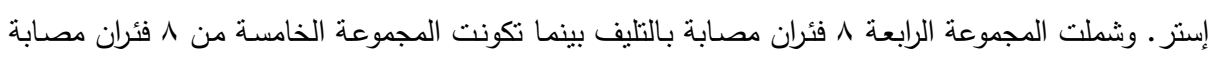

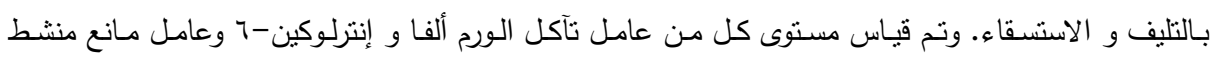

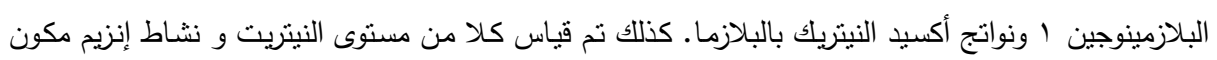
أكسيد النيتريك بالكبد.

النتائج: أوضحت النتائج وجود زيادة ذات دلالة إحصائية ملموسة فى مستوى عامل نآكل الورم-ألفا

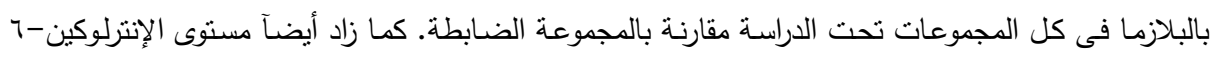

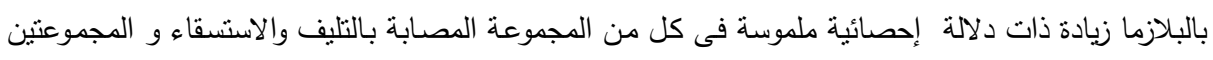

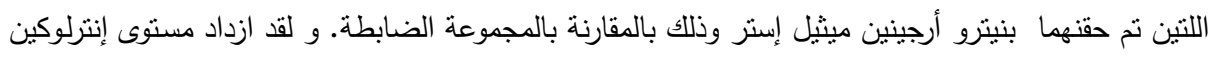

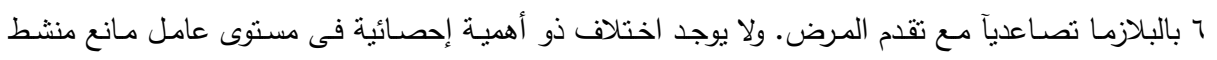

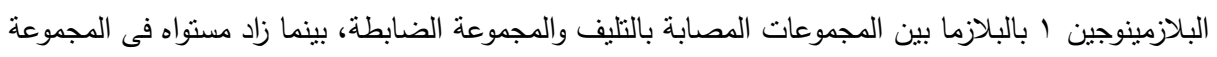

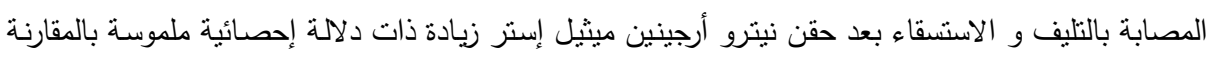

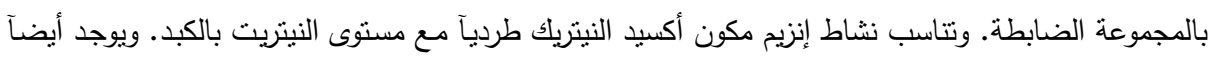

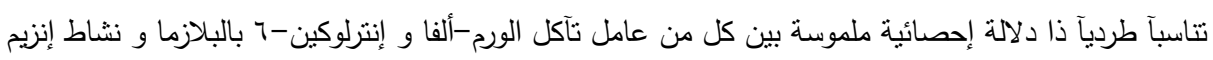
مكون أكسيد النيتريك و مستوى النيتريت بالكبد في الفئران المصابة بادية بالتليف.

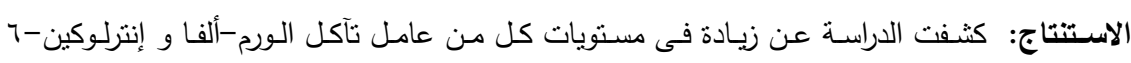

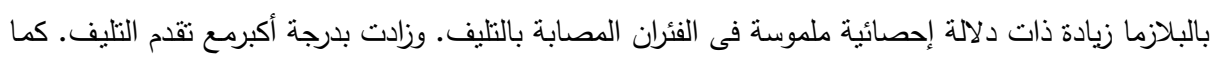

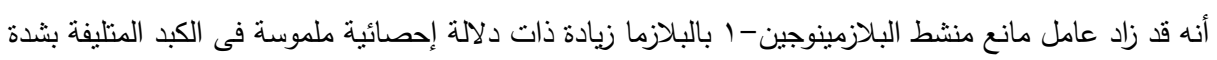

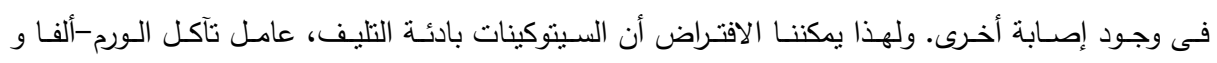

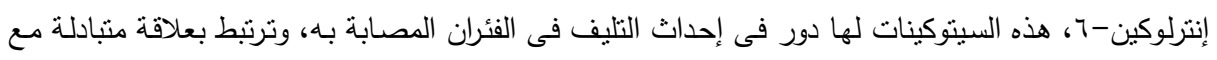

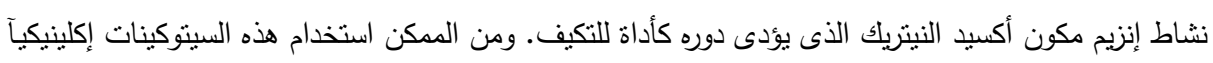

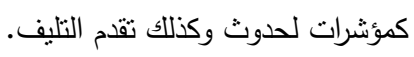

